\title{
The Conceptualization of Khat, Its Production and Its Socio-Economic Implications in Eastern Ethiopia
}

\author{
Tensay Hailu \\ Department of Social Anthropology, Wolaita Sodo University, Sodo, Ethiopia
}

Email address:

tensayhailu@wsu.edu.et

To cite this article:

Tensay Hailu. The Conceptualization of Khat, Its Production and Its Socio-Economic Implications in Eastern Ethiopia. International Journal of Education, Culture and Society. Vol. 4, No. 3, 2019, pp. 54-59. doi: 10.11648/j.ijecs.20190403.12

Received: June 2, 2019; Accepted: July 8, 2019; Published: August 19, 2019

\begin{abstract}
This research tries to analyze the conceptualization, production and socio-economic implication of Khat in eastern parts of Ethiopia. Different reasons have triggered the researcher to do this research. The growing number of khat consumers, the lack of scientifically studies research on this specific issue and the emotional attachment that the researcher has with both the study area and the herbal are some of the triggering factors for writing this manuscript. The researcher has stayed in the major khat producing areas of eastern Ethiopia from December 23, 2018 to January 28, 2019. In this time, the researcher did both formal and informal conversation with khat producing farmers, consumers and traders, observed plots where khat is produced and did interview with elders who are believed to know the history and the influence of khat in the region. Moreover, as an anthropologist, the researcher has participated in social gathering where khat is consumed and did participant observation with the researched communities in the region. All informants were selected purposely based on their affiliation to the topic and their presumable knowledge of the topic as well. After intensive data collection, the researcher came up with findings that illustrate the conceptualization of khat, its production and ad its socio-economic impact in the eastern part of the country. Ethiopia.
\end{abstract}

Keywords: Khat, Production of Khat, Conceptualization, Socio-Economic Importance

\section{Introduction}

Khat is an herbal that has stimulating effect to its consumer. This plant is mainly produced in the eastern part of Ethiopia. Many people in this region based their mode of subsistence on producing this herbal. According to my informants, some farmers are even fully focused on producing Khat. Due to this reason other agricultural production are rarely produced there. Moreover, consumption of Khat is very high and equally the production is getting increased from time to time.

Irregularities in different policies of the country however have been the biggest problem of the production of Khat. Sometimes, the policies at hand and what is done practically around check points is quite different. The government of Ethiopia in this regard failed to get a clear policy either to abandon or allow the production of Khat and exchange of this herbal in market places [1]. For instance, the production of Khat is completely abandoned in the northern part of Ethiopia and people produce it secretly and sell it in a way that officials can't see them. Consumers of this plant are also socially segregated and using this herbal is conceptualized as a bad habit and manifestation of evil [1].

The trend of producing Khat and consuming it in eastern Ethiopia however is quite different. Here in this part of the country, people openly produce and consume publicly as many people do it openly. Producing Khat has its own peculiar trend and process than the rest of agricultural products. Hence this manuscript tries to see the nomenclature and historical background, reasons for the rapid expansion of Khat, the way Khat is produced in this region, the way Khat is conceptualized among the wider public and the socioeconomic importance of Khat in eastern part of Ethiopia.

\section{Methodology and Methods}

\subsection{Methodology}

This is a qualitative research. Qualitative Research is primarily exploratory research. This methodology is basically 
used to gain an understanding of underlying reasons, opinions, motivations, conception regarding khat. Qualitative Research is also used to uncover trends in thought and opinions, and dive deeper into the problem.

\subsection{Methods of Data Collection}

Since this research is a qualitative research, the researcher employed Qualitative data collection methods. Some common methods include focus groups (group discussions), individual interviews, and participation/observations. The sample size is typically small, and respondents are selected purposely based on their affiliation to the concept raised and knowledge on the topic.

\subsubsection{Primary Sources of Data}

Focus Group Discussion (FGDs): Total of 6 FGD sessions were undertaken. Those FGDs were conducted in major Khat producing areas of eastern Ethiopia namely Aweday, Gelemso and Fedis. The FGDs conducted in each Woreda are comprised of one female and one male FGD sessions. Hence, total numbers 42 participants were involved. Each focus group consists of six up to eight participants including community representatives (stakeholders, government officials, curators, elders, community leaders). Semi structured interview question was employed during discussions.

Key Informant Interviews (KII): Key informants from the community were also involved for deep interview sessions. Open ended interview questions and guideline were used in face-to-face interview session. The researcher has got rich information regarding the historical background, challenges, significances, and possible developmental intervention and policy directions through key informant interview. Participants were selected purposely from different stake holders, national, regional, Zonal and Woreda officials; elders, community leaders. Total numbers of 15 key informants were used to provide information regarding the concept under question.

Observation: observation is the means by which we can understand facts that we might not access through other techniques. This technique helps to understand beyond the explanation of informants through interview or group discussion. Hence, observation was selected to be one of our data gathering techniques just to grasp information about the unsaid things during the interview and focus group discussion session.

In this regard, observational checklist was prepared before the actual fieldwork activities. During data gathering process in the field, the researcher observed how Khat are produced, distributed and consumed. Moreover market and social networks intertwined with Khat selling business was also observed. Things that are observed in the field were arranged in a way it is coherent and integrated with the data gathered through other techniques.

\subsubsection{Secondary Sources of Data}

Literatures which are published, unpublished and online sources will be used to have some sort of data on different key concepts, background of the study area and key findings on similar topics. Such data will be used to have pertinent backgrounds, make comparison and have better presentation of empirical data gathered from the field. In that, researchers will use different books, researches, non-Wikipedia on line sources, archives and institutional and governmental documents.

\section{Result and Discussion}

\subsection{The Nomenclature and Its Historical Background}

Khat is known by its different names among different people across the north eastern Africa and the Middle East. To mention some, Chat, Absinian Tea, Miraa, Arabian tea, Ethiopian coffee and other ${ }^{1}$. The work Khat however is widely used these days especially by the scholars of these days. Contrary to the diverse naming, Khat producers and consumers of Ethiopia, especially those in the eastern Hararghe clam that the original name of the plant is Jiima, which is an Oromiffa word meaning ever green plant having the effect of lifting a sprit. Despite elders of that area are still using the word Jiima to call khat, many people especially the youth are tending to call the herbal as Khat. Moreover, different market places where Khat is exchanged are named after the name khat not Jiima despite they call the herbal as Jiima.

The history of Khat production and consumption still remain unclear, where lots of historians claim different areas as the birthplace of Khat. Because of a massive production, consumption and distribution of Khat in Hararge ${ }^{2}$, some historians consider the area as the birthplace of $\mathrm{Khat}^{3}$. Contrary to that there are other written accounts which deal with the subject of the beginning of Khat consumption and production. A document entitled pharmacy in the healing Art suggests that Khat was known in Turkistan and Afghanistan as early as the beginning of $11^{\text {th }}$ Century.

Even though some scholars stated Ethiopia as the birth place of Khat, despite scholars of the Middle Eastern country believe otherwise. Many scholars put southern Arabia and the red sea coast as the birth place of Khat. The roughly stated geographical setting includes the old Ethiopian Kingdome called Axum. However the chronicle of Emperor Amde Tsion suggests the observation of Khat by the emperor during his invasion to Ifat kingdom I 1330. In the emperor's chronicle the king of Ifat by the name Sebra'din is quoted as saying "I will take my residence at mar'ade and I will plant Khat there because the Muslim want that plant for medication". The

1 Hizkeal Gebisa (1996) wrote the different names that khat is been called across different countries. For instance khat is called Mirra in Kenya.

2 Hararghe is the name derived from the city of Harar. The area covers massive land in between Chiro, western Hararghe to Harar and its surround areas, eastern Hararghe.

3 Yeraswork Admase (2017), the conundrum of khat in Ethiopia: Socio-economic Impacts and Policy Directions, Forum for Social Studies, Addis Ababa. A traveler called Sir Richard Burton (1856, Vol I.) has clearly mentioned Hararghe as the birthplace of Khat production. 
story suggests the use of khat was familiar practice among the Muslim communities in east central Ethiopia in $14^{\text {th }}$ century.

Studies in Hararghie [2] show that the production of Khat from the end of the 19th century until the 1940s focused on satisfying local demand. Traditionally, Khat was used by Muslims during prayers and other religious activities such as reading of the Koran. According to the farmers, the oldest Khat plantation in the Hararghe area was believed to be planted in the1920s, indicating that its use has a long tradition in Hararghie.

However, khat cultivation as a cash crop began earlier in eastern Hararghie than in western Hararghie as a result of access to transportation and wider market opportunities. Cultivation as a cash crop in western Hararghie (particularly in Habro) began in the 1970s, according to the farmers. Khat production has expanded since 1970. Khat was only cultivated on about 5 hectares of the land of the farmers surveyed before 1970, whereas today it is cultivated on 34 hectares of this land [3]. Currently very few farmers are non khat growers.

Khat is now consumed almost in all corner of the world. Especially youths prefer to use this plant due to its high stimulating effect and very easy access to it. However, many of these consumers did not know where this plant is coming from and the history of the plant [11]. Ethiopia is the world's largest producer of khat, which is the country's fastest growing export ${ }^{4}$. About a third of the production is exported to Djibouti and Somalia, but the bulk of it is marketed and consumed within the country, mostly in the Somali administrative region.

\subsection{The Conceptualization, Expansion and Nature of Production of Khat in Eastern Ethiopia}

\subsubsection{Conceptualization of Khat Among Its Consumers}

khat has social, cultural and religious importance in many areas of the eastern corridor. khat is used to arrange different get together, community dialogues and discussions. During such events Khat is always used to stimulate the process [12]. People share their khat and express their love for the person they are sharing their khat. During interview session, one of my informants named Adem Guyo said,

I cannot even imagine what I can do if there is no khat in such social gathering. I don't even come to such events if I have no chat in between my armpit.

Many of my informants have responded that many people chew Khat with their friend or someone who can sit with them and share ideas on their personal life, community problems and their solution. In short, Khat triggers dialogue between people since chewing Khat needs staying in certain places for hours. Contrary to this, some people who are reached to the high simulative effect (Mirqana) prefer to stay

4 According to Taye and Jens (2003), Ethiopia produce khat and export to many eastern Africans who themselves produce khat but not enough for their market like Kenya, Sudan, Djibouti, Somalia and other non-eastern African countries like Yemen, Canada, U.S.A. and Netherlands. silent. Hence some people say, even though Khat has a greater influence in triggering social gatherings, it has a little effect in triggering dialogue since majority of chewers prefer not to talk while chewing Khat.

One of my informant who is from the biggest city of Hararghe, Awaday said he has no intention of stopping Khat. Khat for him Khat is a means for entertainment, but also it is a means by which he achieves what he wants to do in school and working place.

Khat is also associated with religious actives. Especially the Muslim community consider it as a shrub which strength them to stay strong during praying times [11]. Especially during the Ramadan moth when the Muslim community start to fast and pray to their God, they mostly stay active the whole night till they eat what traditionally called Suhur ${ }^{5}$ In order to stay as long as the mid night, the family needs some stimulating ingredients to use. Historically, Khat was in use to play this role among the Muslim community and still, the Muslim community uses it for being active till the mid night [13].

\subsubsection{The Expansion and Nature of Production of Khat Expansion of Khat Production}

Both socioeconomic and agro ecological reasons have contributed to Khat expansion. The driving forces have probably been increased market opportunities and favorable prices. Production is mainly located close to the road network and on farms with irrigation facilities ${ }^{6}$. The profitability of Khat production is considered as the primary reason for the expansion of Khat production in the Hararghe area.

The average income (59 farmers) from the intercropping system of Khat and maize is 3465 birr/ha, of which Khat accounts for $80 \%$. Income from maize mono-cropping is only $1306 \mathrm{birr} / \mathrm{ha}$. The income from the intercropping system is therefore 2.7 times higher than from the mono-cropping system. The high profitability of Khat has also motivated farmers to hire labor for Khat production [12].

Another study in eastern Ethiopia found that particularly young farmers with small farms expand Khat production [4]. Other factors contributing to expansion include low risk and low labor inputs compared with cereal crops. Ownership of Khat plots is also considered important when a man proposes marriage to a woman. Decrease in the productivity of the land is the second most important reason why farmers expand Khat production. Production has expanded particularly at the expense of annual cropping (maize, sorghum), but land under coffee has also been reduced.

The major agro-ecological constraint of annual crops and coffee is drought, and Khat serves as a good substitute for these crops because it is less vulnerable to drought. Other

\footnotetext{
5 Hizkeal G (2004) wrote Suhur is a food that fasting community eats just before fasting is started. Members of a family collectively eat Suhur before the rise of the sun at about $4 \mathrm{AM}$.

6 According to Hizkeal G (1996), any of the irrigation facilities are being built by the farmers by themselves. There is very limited intervention of the government in helping the farmers get facilities like they do for the production of other cash crops.
} 
agro-ecological factors that have triggered the change from annual crops to Khat, according to farmers, are lack of oxen for plowing, soil erosion, weed infestation, and the prevalence of pests and diseases. Lack of oxen was an important production constraint in the past because oxen were needed to plow the land in the cereal production system. Oxen are needed much less in the Khat-based system because tillage is mainly done by hoeing ${ }^{7}$.

Farmers also lack the financial resources to purchase fertilizers necessary for growing cereals. Khat however need no further investment one it is planted. The planting of Khat is also considered by farmers in the area as a way to ensure land entitlement because annual cropland is more affected by land redistribution than land under perennial crops. Khat producers can also more readily gain access to labor because they can offer Khat to the workers. Credit is also more easily available for Khat growers ${ }^{8}$.

\section{The Nature of Khat Production}

Khat is a tree reaching $25 \mathrm{~m}$ when grown naturally, but is generally kept to $1.5-4 \mathrm{~m}$ when cultivated as a cash crop. Khat occurs naturally in East Africa at elevations between $1,500 \mathrm{~m}$ to $2,500 \mathrm{~m}$ above sea level. Once established it grows well under a wide range of soils and climatic conditions, having a better drought tolerance than coffee. It can be grown in dry areas with irrigation, but does not tolerate poor drainage and does not do well in wet soils. It performs best in the midlands (weyna dega) between $1,500 \mathrm{~m}$ and $2,100 \mathrm{~m}$ above sea level, but is cultivated in Hararghe into the lower dega, until around 2,400 $\mathrm{m}$ above sea level, if not too cold and frost free [5].

The wood of Khat trees is suitable for cabinet work, fuel wood and appreciated for house construction as termites do not attack it, while different parts of the tree are used as local medicine. Khat is cultivated as a cash crop for its young leaves and tender stems chewed as a mild natural stimulant, which, like coffee or alcoholic beverages, plays an important role in the social life of people in Ethiopia in general and in Hararghe \& Somali Region in particular. It is also highly appreciated in neighboring Somalia, Djibouti and Yemen. Its use in Africa and the Arabic peninsula goes back to the 13th century [6].

In Hararghe Khat is generally planted on hillsides, in rows along contour lines on level bunds (spacing in the row $1 \mathrm{~m}$, between rows $2 \mathrm{~m}$ ). On reasonably fertile soils Khat is intercropped with maize and other food crops, whereas on steep slopes and marginal land it is grown in pure stands. Alongside with the progressive development of Khat production, farmers add additional rows in between, finally reaching pure stands. Pure stands have been more frequently observed in West Hararghe. Khat is usually planted or transplanted in August by vegetative propagation from

\footnotetext{
7 According to my informants Khat needs continues hoeing and follow-ups unlike other cereal productions. The hoeing however can be done by a young man or a girl or even by an old lady.

8 According to participants of our FGD, Khat producers get credit very easily than other cereal producers. This is due to the fact that Khat producers can get the yield any time and get money when they present it to the market.
}

suckers or branches. Irrigation is used whenever possible, to increase the number of main harvests, the yield, the quality and the price [10].

All consulted farmers apply manure, generally once a year, with some farmers using also chemical fertilizers according to cash availability. Weeding and harrowing is done around three times a year. Few farmers are mulching their Khat plantation. Aside of harvesting, pruning is done every three to four years to rejuvenate the plants. Defoliation is practiced by part of the farmers, either in bad years during the dry season or to obtain best quality. Khat is believed to decrease soil fertility and to have some negative effects on neighboring crops from shade, concurrence of nutrients and moisture. The widely used practice of intercropping somewhat attenuates the statement of the farmers and might mainly apply for Khat plantations with narrow spacing between rows $2 \mathrm{~m}$ [3].

Khat in Hararghe is not highly affected by pests and diseases, a situation which might slowly change for the worse with increasing density of plantations. Some fungal diseases can be observed during the rainy season, whereas insects are the main cause of damage. To control the infestations, farmers collect insects by hand, apply locally produced remedies (e.g. a mixture of crushed tobacco leaves, garlic \& soap) or even spray insecticides.

Rain fed Khat gives a maximum of two main harvests towards the end of the rainy seasons. Under irrigation three and more main harvests can be realized and eventually timed to fall into a high price period ${ }^{9}$. In addition, lower quality Khat is harvested all through the year, sold on local markets and used for home consumption. On the average Khat yields around 700-1,000 kg per hectare.

Main problems with chat production mentioned by the farmers were: shortage of manure, high price for chemical fertilizer, lack of credit facilities and low availability of irrigation possibilities. But still many Khat farmers feel that the challenges they face for producing Khat is relatively easier.

\subsection{Socio-Economic Importance of Khat}

\subsubsection{Social Importance}

Khat production has become the major source of income in eastern Ethiopia particularly in Hararghe. The average annual household income of the targeted sample is 28,000. A consequence of Khat expansion is that farmers need to buy cereals to meet their food requirements. The total average expenditure on food purchase per family is $11,000 \mathrm{birr} / \mathrm{year}$. Each family has an average of 6.3 members. Data from the present study do not allow the conclusion that Khat growers in the study area are better off than non Khat growers, but the general impression is that Khat growers have better houses,

9 Hizkeal (1996) noted that a single Khat plant can be harvested frequently but the quality of the khat will be decreased. In order to get quality khat and maximize the price of the khat, farmers harvest twice or three times in a year. However, farmers harvest every weekend in shift. That means a single khat plant will be harvested three or two times in a year. 
wear better clothes, have better household equipment, and are in a better position to send their children to school.

However, Khat production has not solved the problem of food security in the district. The households' own production of food crops lasts an average of 7.3 months, whereas if purchased food is taken into consideration, households have enough food for 10.7 months. The survey showed that $51 \%$ of the households have enough food throughout the year.

Khat consumption negatively affects the working capacity of people because Khat consumers show up late for work, take frequent rests, spend time chewing Khat, and are generally more careless. This is also the reason why Khat consumers are paid less than non Khat users. Currently, unskilled Khat consumers in urban centers are paid 30 birr per day, whereas unskilled non Khat users (migrants from Amhara) are paid 40 and above birr per day [2].

Khat consumption is widespread among both males and females. All the male heads of the surveyed households consume Khat, and $81 \%$ of the population above 15 years of age in the surveyed households uses Khat. In the nearby secondary school (Gelemso), the survey showed that $88 \%$ of the female students and $96 \%$ of the male students use Khat. The consumption of Khat has serious social consequences, and consumers spend a high portion of their income to purchase Khat. Khat consumption is known to induce mild euphoria and excitement [2].

Individuals become very talkative under the influence of the drug and may appear to be unrealistic and emotionally unstable [7]. Khat can also induce manic behavior and hyperactivity. From Somalia, it is reported that Khat consumption promotes different types of criminal activities [8]. However, there are also positive effects of Khat production. In addition to income generation for farmers, employment is created in transport and trade concerned with Khat.

\subsubsection{Economic Importance: The Case of Awaday Town}

Awaday in Ethiopia's east is the heart of the country's Khat world. The cash crop is traded 24 hours a day, the busiest hours being from down to $9 \mathrm{am}$. Bundles of $\mathrm{k}$ Khat hat are packed in makeshift sacks amongst other leaves for safety and the worth of the pristine harvest can sometimes be as high as \$2000 USD a bunch. Trucks leaves Awaday daily heading to destinations such as Djibouti and Somaliland to deliver the highly demanded leaf. It is estimated that 45,000 kilograms of Khat are sold in Awaday only. Many women are big traders in Awadays's market, while men are engaged in finance related activities, transporting, packing and carrying the Khat from place to place [3].

The Khat market is a bustling space, pushing, shoving and being grabbed by the shoulders is all common practice in the aisles of the market place. Despite all the hustles the Khat markets like Awaday have created different job opportunities for different people. Some of the job opportunities in that social space are discussed below.

1. Khat Merchants

Khat sellers are mostly women who inherited the business from their family. They buy Khat by going directly to the farmers' land where the Khat is planted. According to informants best Khat could be sold before the harvest. One informant further told me that

Khat merchants know the hardworking merchant who always produce the best and highly demanded Khat. So such farmers always sell their Khat even before the plant is ready for yielding. Sometimes however, the farmers themselves might bring their Khat to the market and sell it to retailers or sell it to the consumer through experienced Khat sellers who are paid by the farmer for their service ${ }^{10}$.

Informant, February 21, Awaday

After a series of observation of the market and informal conversation with Khat merchants, the researcher came into conclusion that there are two types of merchants. These are whole selling merchants and retailing merchants. The whole selling merchants did not come to the market frequently. They buy the Khat directly from the farmer in bulk and distribute it to retailers who are their regular customers. The researcher also informed that some whole sellers are also engaged in exporting the Khat. This business is overwhelmingly done by rich business men who have other business other than Khat trading. Women are mostly engaged in retailing of Khat. There are also some women retailers who directly buy the Khat from the farmer in bulk and sell it to the consumer by themselves.

2. Arranging Khat for Market

Khat did not go to the market directly from the agricultural field, but it will be prepared for the market. Preparing it includes activities like cutting the Khat from the main branch, removing unnecessary leaves, packing it in a way it weight 1 kilogram ${ }^{11}$ and as well packing it in a way it can be transported to the market.

Females mostly prepare khat in a way suitable and preferable in the market. It is believed that the reason for that is the job has no ups and down that would restrict females from doing it. However, females prefer the job when it is only done during the day light. Here, if the owner of the Khat or the exporter has more Khat to be prepared, then he/she hire female workers during the day and male workers for the night shift [9].

There are thousands of such workers in different parts of Hararghe. Many job seekers however, prefer to come to bigger cities like Dire Dawa, Harar, Awada, Hirna and Chiro. In these towns, there are many Khat exporters who seek workers. Moreover, according to majority of my informants, very experienced and rich Khat exporters are available in the above mentioned towns. Hence, many workers migrate to these towns for seeking job that is basically related to Khat.

3. Transport Workers

From the beginning to the end, Khat needs three form of transportation; the first is the form of transportation through

10 Informant (Interviewed Feb, 21, 2019)

11 According to my informant (Interviewed Feb, 21, 2019), they don't use measuring instruments. Because they are experienced enough to know a one kilogram khat by observation and handling between their palm, they don't use any other instrument. 
labor force. Here, young labor workers are engaged in transporting the Khat usually to Khat processing shades, where Khat is made to be ready for consumption. These labor workers put it in their shoulder and hold it till they reach to the point they move the Khat. Immediately after the arrival of the Khat in the processing unit, it will be prepared for consumption and they load it to cars, usually a japan made car named Isuzu. Here the car loads lots of Khat as much as the available Khat. Cars are usually used to move the Khat to major markets of the region like Dire Dawa. These days most of the cars are owned by the farmers so that they do not pay for car transportation ${ }^{12}$.

The other transportation system that is engaged to Khat related business is air transportation. Air is basically owned by the government. This mode of transportation is used basically for exporting the Khat to neighboring countries like Djibouti and Somalia. Farmers are not involved in exporting Khat. Rather exporting Khat is the business of whole sellers who distribute Khat. In some cases private air crafts are used by those Khat exporters. A very good example in this regard is the air craft owned by Ms. Sura. She is one of Khat exporter in the eastern part of the country. Sura predominantly exports Khat to Somalia and other places. Because she exports lots of Khat, she owned her own air transportation named Sura airline, which now terminated its flight.

\section{Conclusion}

Khat is the most important substance and center of every ritual, social gatherings and ceremonial events in eastern Ethiopia mostly referred as Hararghe region. The leaf is used to stimulate a person who is chewing the leaf during ritual and social gatherings. Chewing Khat in group triggers peaceful dialogue on different matters of the community. Khat consumption also has negative effects on the working capacity of people. This is because Khat consumers show up late for work, take frequent rests, spend time chewing Khat, and are generally more careless. This is also the reason why Khat consumers are paid less than non Khat users. Despite the negative effects of Khat consumption, the number of Khat consumer is increasing in alarming rate among both males and females.

Khat has become the backbone of eastern Ethiopia's economy. Ever increasing number of people is directly or indirectly benefited from Khat and Khat related business. Farmers who produce Khat moreover are the outmost beneficiaries of the business. Khat merchants in every town of eastern Ethiopia corridors, Khat arrangers who make the leaf ready for consumption and transportation workers are the other beneficiaries of the business. The engagement of the above-mentioned section of people in Khat business has positively affected the household that they represent since most of them financially subsist their respective households.

\section{References}

[1] Taye Hailu Feyisa and Jens B. Aune. 2003 Khat Expansion in the Ethiopian Highlands: Effects on the Farming System in Habro District, Mountain Research and Development, Vol. 23, No. 2, pp. 185-189.

[2] Getachew M. 1996 The Cultivation of and Use of Khat Among the Oromo of Harar with Particular Reference to Haromaya Woreda. Addis Ababa, Ethiopia: Addis Ababa University.

[3] Hizqiel Gebisa. 1996 consumption, Contraband and Commodification: A history of Khat in Hararghe, Ethiopia e. 1930-1991, A PhD Dissertation.

[4] P. J. Greenwa. 1947 Khat, the East African Agricultural Journal, 13 : $2, \quad 98-102, \quad$ DOI: 10.1080/03670074.1947.11664588.

[5] Getahun, A., and A. D. Krikorian. 1973 Chat: coffee's rival from Harar, Ethiopia. I. Botany, cultivation and use. Economic botany, 27: 353-377.

[6] Peters, D. W. A. 1952 Khat: its history, botany, chemistry and toxicology. The pharmaceutical journal, 169: 17-18.

[7] H. Richard, Mustafa al'Absi. 2010 Khat Use and Neurobehavioral Functions: Suggestions for Future Studies, Journal of Ethnopharmacol, 132 (3): 554-563.

[8] Beke, T. Charles. (1843) On the Countries South of Abyssinia, Journal of the Royal Geographical Society, London, $23^{\text {rd }}$ November.

[9] Yerasework A. 2018 The Khat Conundrum in Ethiopia: Socio Economic impact and policy Direction, Forum for Social Studies (October 31, 2018), Addis Ababa.

[10] Amare Getahun and A. D. Krikorian. 1973 "Khat: Coffee rival from Harar, Ethiopia: Botany. Cultivation and Use" Economic Botany, 27 p354.

[11] Bally, P. R. O. 1945 Catha edulis. East African medical journal, 22: 2-4.

[12] Cassanelli, L. V. 1986 'Qat: Changes in the Production and Consumption of a Quasilegal Commodity in Northeast Africa'. In The Social Life of Things: Commodities in Cultural Perspective, Appadurai, A. (ed). Cambridge: Cambridge University Press.

[13] Hizkeal G. 2004 Leaf of Allah: Khat and Agricultural Transformation in Harage, Ethiopia 1875-1991. Oxford: James Currey Publishers.

[14] John Spencer Trimingham. 1952 Islam in Ethiopia, Barnes \& Noble, London, p228.

12 According to my informant Ayub Aliye (Interviewed Feb, 18, 2019), financially rich farmer could have his own cars while other buy cars in a group so that they don't pay for transporting their khat to the market. 